\title{
Confronting Cultural Barriers in Public Speaking through Multiple Learning Strategies: A Case of Indonesian EFL Learners
}

\author{
Concilianus Laos Mbato \\ Master's Program in English Education, Sanata Dharma University, Yogyakarta, Indonesia \\ Email: cons@usd.ac.id
}

\begin{abstract}
Cultural barriers, anxiety and lack of English competence may lead to EFL students' failures in public speaking. Conducive learning environments, right coaching and learning strategies are likely to increase the possibility of students' success. This research aimed to investigate whether the implementation of multiple learning strategies empowered Indonesian EFL students' public speaking skills. 56 students enrolled in three public speaking classes of Sanata Dharma University, Yogyakarta in the academic year 2017-2018 participated in the research. One overriding research question was postulated, i.e., to what extent does the implementation of multiple learning strategies empower students' public speaking skills? To answer the question, classroom mixed-methods research was employed where students filled out four different questionnaires and submitted focus group discussion (FGD) results at the end of the semester. Quantitative and qualitative data analyses indicated that students had very high perceptions about the use of and the combinations of reflections, peer-, teacher-, and self-assessments, independent learning plans and activities. They believed that multiple learning strategies implemented in the Public Speaking Class enabled them to be independent, responsible, and better learners. They also acknowledged becoming more confident and better public speakers. This study contributes to the body of knowledge in public speaking in two important ways. First, learning to speak in public for non-native speakers of English should begin with raising their awareness about cultural barriers that might inhibit the development of the necessary skills in public speaking. Second, teaching public speaking to EFL students requires the adoption of multiple learning strategies including strategies to confront imminent cultural barriers. This research, therefore, urges public speaking trainers and teachers in EFL settings to include intercultural understanding and multiple learning strategies in their public speaking classes in order to empower students' public speaking skills.
\end{abstract}

Keywords: public speaking; learning strategies; reflection; assessment; independent learning; Indonesian social and cultural values; confidence; intercultural understanding

\section{INTRODUCTION}

Being able to speak in English well has driven many EFL learners around the world, including those in Indonesia, to pursue English language learning either at formal or nonformal language learning institutions. In recent decades, EFL learners are not only expected to speak well in English but also to perform public speaking activities in English successfully. Public speaking skills become inevitable in the $21^{\text {st }}$ century's learning, life and employment owing mostly to the globalization of information, technology, commerce and fast interactions between people from different nationalities, (see Apriyanti, Syofiani, Ramadhan, \& Mukhaiyar, 2018; Mabuan, 2017; Watkins, 2014; Yee \& Abidin, 2014). Responding to globalization challenges, higher education institutions in many parts of the world internationalize their curricula to include public speaking skills (Boromisza-Habashi, Hughes \& Malkowski, 2016). 
Public Speaking is a compulsory course for English language students at Sanata Dharma University, Yogyakarta, Indonesia. Through more than twenty years of teaching at the university, I found that Public speaking becomes one of the most challenging courses for students. To be successful, they need to possess a number of skills such as good language production (pronunciation, voice volume, fluency, grammar and articulation), an ability to speak in front of an audience, good confidence and interaction with the audience, body language and movement, content mastery, organization and delivery, and perfect time management. In addition, students need to develop intercultural competence. Being interculturally aware increases the likelihood of EFL/ESL learners' success in improving their speaking skills (see, Omar \& Altaieb, 2015). Students even face a greater challenge when their performance is assessed not for learning purposes but for testing. This observation confirms Pawlak's (2018) assertion that, despite the available online learning materials, non-native speakers learning English in a foreign language setting find speaking in English challenging.

Public Speaking may lead to students' increased level of anxiety and stage fright (Bippus \& Daly, 1999; Durlik, Brown \& Tsakiris, 2014; LeFebvre, LeFebvre \& Allen, 2018). In their research on 192 students at Introductory Communication Courses at a large public university, Bippus and Daly (1999) found five major causes of stage fright, i.e., feeling afraid of committing mistakes, not knowing what role to play during speech, feeling humiliated, and failing to perform well (p. 70). They suggested these factors be openly and frequently addressed in any public speaking training.

Several studies on public speaking have been conducted in Indonesia (Anandari, 2015; Apriyanti, Syofiani, Ramadhan, \& Mukhaiyar, 2018). Anandari (2015) found that having to speaking in public led to students' anxiety, which might be attributable to their social and cultural backgrounds. Indeed, people's attitudes, awareness and actions reflect their cultural beliefs and influence how they communicate in a society (Retnowati, 2015, p. 341). Regarding Indonesians' style of communication, Moffatt (2012) asserted that they tend to communicate indirectly, softly and very carefully in order to avoid public shame. They also like to use body language and gestures to get the message across. Indonesian people, most notably Javanese, like to conceal their emotions, communicate indirectly, avoid being held responsible and prevent public attention (see, e.g., Abdullah, 2016; Nadar, 1999, p. 2). They uphold balance and affinity (Hermawan \& Loo, 2019).
On the one hand, these cultural traits may prevent Indonesian students from gaining success when they have to speak in public. On the other hand, Indonesian people have a tendency to welcome foreign values as long as they do not contradict with local wisdom as was the case with the integration of the Western style of democracy into Yogyakarta's government system (see Tolo, 2013). A study of different cultures in Indonesia's Cirebon City (Humaedi, 2013) found that the meeting of these cultures resulted in a cross cultural understanding, which in turn may lead to the birth of a new culture. Similarly, Kusciati, Susilorini, and Febriary's study (2013) on Javanese Moslem females who wear modern veils revealed that these young women embrace practical, free and autonomous ideas while at the same time clinging to the more traditional Javanese values such as politeness and respect. Research by Andries (2018) also suggests that in forming their identity, Indonesian people embrace cultural dialectics, which are gained through dialogues, good relationships and adjustments. A more recent study (Andriani, Udasmoro, \& Suhandano, 2019) indicates that, when faced with foreign cultures, Indonesians tend to assimilate, dismiss or adjust themselves with such cultures. These examples should be encouraging for teachers and trainers in public speaking in that, given the right environment, coaching and learning strategies, Indonesian learners of English could overcome cultural barriers and develop the necessary skills to enable them to perform public speaking successfully.

Since Public Speaking is quite demanding and may be connected to students' cultural and social values as discussed previously, teachers need to develop some teaching strategies that could help students reduce the level of anxiety and focus on empowering themselves particularly in the contexts of foreign language learning (cf. Dornyei, 2005; Dornyei \& Ushioda, 2013; Jin, 2015, p. 59; Mbato, 2013).

Research about public speaking by Indonesian researchers has so far been focused on a single strategy to facilitate students' learning (cf. Anandari, 2015; Apriyanti, Syofiani, Ramadhan, \& Mukhaiyar, 2018). In the current study, Indonesian students were provided with ample opportunity to develop multiple learning strategies that could empower them to diminish cultural stumbling blocks when conducting public speaking (for a discussion about Indonesian culture, see e.g., Abdullah, 2016; Hermawan \& Loo, 2019; Moffatt, 2012, Nadar, 1999, p. 2) and enabled them to focus on regulating their motivation to speak in public confidently and successfully. Teachers should not rely on students' own ability to manage the learning environment in order to maintain motivation and 
reduce anxiety as was the case found in Chaffee, Noels and McEown's study (2014). Rather than encouraging EFL learners to develop speaking strategies on their own, teachers need to envisage concrete actions to support them. As argued by Pawlak (2018), little research has been conducted on students' speaking strategies.

Authors on Indonesian cultures mentioned above (see, e.g., Kusciati, Susilorini, \& Febriary 2013; Andriani, Udasmoro, \& Suhandano, 2019) have argued that while clinging to their traditional cultural values, Indonesians are mostly open and adaptable to foreign values and cultures. This research furthered the argument by empowering Indonesian students to develop and make use of their intercultural understanding and various learning strategies to enhance their public speaking skills. It argued that motivated and resilient learners should be nurtured through teaching strategies that focused on creating a positive learning environment for students to experiment with learning and empower themselves.

The present study aimed to fill in the gap and enrich the current literature by reporting classroom mixed-method research on three major learning strategies designed to empower public speaking students of Sanata Dharma University in the 2017-2018 academic year, namely: (1) students' reflections about their learning experiences; (2) the implementation of self-, peer-, and teacher-assessment as learning feedback rather than merely as grading tools; and (3) independent learning activities where learners had the freedom to plan, monitor and evaluate their learning independent of the teacher's intervention. These three learning strategies were undertaken based on a public speaking rubric provided by the teacher.

The current research addressed one overriding research question:

To what extent does the implementation of multiple learning strategies empower the students' public speaking skills? This question was elaborated into four sub-questions:

1. What are the students' perceptions about the role of reflections in public speaking?

2. What are the students' perceptions about the role of peer-, teacher-, and self-assessments in public speaking?

3. What are the students' perceptions about the combination of multiple learning strategies in public speaking?

4. Is there a difference in students' perception about their public speaking skills before and after participating in public speaking class?

Based on this research question (4), a null hypothesis and an alternative hypothesis were formulated:

Ho: There is no significant difference in students' perception about their public speaking skills before and after taking public speaking class.

H1: There is a significant difference in students' perception about their public speaking skills before and after taking public speaking class.

\section{LITERATURE REVIEW \\ Learning strategies}

Learning strategies have been defined as students' thoughts and actions that are consciously directed towards specific learning goals (see Oxford, 1990; 1994; 2011; 2017; O’Malley \& Chamot, 1990; Chamot, 2008; 2009a; 2009b) and have been found to facilitate students' learning management and success (see Chamot, 2009a; 2009b; Oxford, 1990; 1994; 2011; 2017; Mbato, 2013). However, as argued above, the students learning English in a foreign language setting needs to be facilitated to empower their speaking and public speaking skills (cf. Pawlak, 2018) rather than making them rely too much on their own abilities to regulate the learning environment (cf. Chaffee, Noels \& McEown, 2014). Learning-centered teaching gives weight to the centrality and integration of independent learning. Therefore, students in this research were encouraged to plan, implement, monitor and evaluate their independent learning activities outside the classroom, make regular progress reports about their learning, and come to class with a learning goal and prepared public speaking outlines.

Learning strategies are central to the students' learning success (Oxford, 1990; 1994; 2011; 2017; O'Malley \& Chamot, 1990; Chamot, 2009a; 2009b; Mbato, 2013). In my class the focus was on designing learning strategies that could nurture students' learning independence and success. As mentioned earlier, students need to think of and develop specific strategies to enhance their public speaking skills. One of the strategies that has gained popularity in literature is metacognitive learning strategy (cf. Oxford, 1990; 1994; 2011; 2017; Chamot, 2009a; 2009b). To be effective, metacognitive strategies should be directed to a certain skill. Mbato (2013) found that specific and achievable learning plans could facilitate students' learning progress and achievements.

In the light of technology advancements, learners could make use of the online learning materials since accessing and applying them have the potential to empower students' public speaking ability (Butler, 2017, p. 9). However, without a well-designed learning strategy, the availability of technological advancements 
will contribute little, if any, to the EFL students' speaking skills (see Pawlak, (2018). Making weekly independent learning plans is a first step for learners to take the learning responsibility into their own hands. Being responsible for their on learning is an important element for the learners to become self-regulated, which in turn will contribute positively to their academic learning progress and achievements (Zimmerman, 2000; 2008; Mbato, 2013; Daniela, 2015).

\section{Reflections}

As an English teacher who has been teaching English as a foreign language for more than 20 years at the university, I realized that learning would be a success when it was well planned, monitored and evaluated. To be able to do so, learners need teachers who are willing to change teachercentered interactions to student-centered learning. Zuniga and Simard (2016, p. 154) point out there is often a lack of fruitful interactions between the teacher and the students despite the long existence of the communicative language teaching. One strategy to create meaningful learning and constructive interactions in class is by supporting students to gain an accurate description of their public speaking proficiency development. Lockley (2013, p. 189) argues that a student's ability to measure their speaking ability correctly will help them to increase their willingness to speak, which in turn leads to increased proficiency. He further argues that (Lockley, 2013) self-evaluation and classroom behavior are related to learners' perceptions about their speaking and communication competence ( $\mathrm{p}$. 190).

Student reflections could be used as powerful learning methods that derive from and make use of experiences (Finlay, 2008). Anandari (2015) and Mbato (2013) in their respective research on Indonesian EFL learners revealed that students' reflections impact their learning positively. By reflecting on and learning from their experiences, students will be able to construct new understanding that may benefit their future language learning (see Scanlan \& Chernomas, 1997). Helping students to build the habits of reflecting about their learning should be an explicit teaching goal at the university (see Hutchings, 2018). Gallego (2014) encourages more research on learners' reflective enterprises (p. 48). It is expected that through reflections, learners would come to class with a positive and accurate perception about themselves and their learning.

\section{Assessment}

Developing effective learning strategies in students requires an integration of peer, teacher and selfassessments. Khonbi and Sadeghi (2013) implemented these three kinds of assessments to 63 Iranian EFL university students and found that in general students indicated a positive attitude towards them. They argued that most testing at the education institutions had focused mainly on standardized testing rather than on their contributions to students' learning (p. 88). Black and Wiliam (2018, p. 3) argue that classroom assessment should enable students to learn something empowering. Abdolrezapour, Tavakoli and Ketabi (2017) in their research about 50 EFL Iranian students' emotions using dynamic assessments argue that "when learners become aware of the learning goals and assessment procedures, they can determine their expectations of success, which in turn enhance their motivation" (p. 232). They found, among others, that cognition, emotions, and dynamic assessments could assist learners to enhance their performance (p. 234). Cheng and Fox (2016, cited in Krajka, 2017, p. 719) emphasize the importance of the interconnectedness between assessments of learners' progress, achievements and learning. Good assessments should motivate students to engage more in learning; they do not stop merely at describing their language competence and skills. This research would enrich the current literature on assessments since assessments were used as a learning tool and were integrated with learning plans and reflections (see discussion below on reflections).

Learners' weekly independent learning plans and activities made use of the self-, peer- and teacherassessments, which were all based on a public speaking rubric, and geared towards learners' metacognitive awareness and strategies to enhance their public speaking skills. The plans were created based on students' understanding of their strengths and weakness (cf. Khonbi \& Seghi, 2013; Mbato, 2013).

Having assessment feedback from various sources was expected to enhance learners' understanding about themselves as learners and prevent misconceptions. For this to happen, I used one public speaking rubric (see Appendix 2, p. 30). The rubric was used by the teacher, the individual students and their peers to assess the students' public speaking performances both inside the class and independently outside the class. The independent learning plan, reflections and assessments are most effective when they are based on the learners' prior learning experiences, which give them a better understanding of their strengths and weaknesses in relation to a certain skill (cf. Khonbi, 2013, p. 88; Mbato, 2013). Metacognitively, good learning will happen when learners monitor and evaluate their 
performances, and plan the strategies to fix the learning problems and improve the learning outcome (cf. Oxford, 1990; 2011; 2017; Chamot, 2009a; 2009b; Mbato, 2013; Mbato 2019).

To the best of my knowledge, there has been little research on public speaking in EFL learning contexts investigating the integration of multiple learning strategies. This research fills in the gap and enrichs the findings from previous research (Anandari, 2015; Jin, 2015; Abdolrezapour, Tavakoli \&Ketabi ; Butler, 2017; Apriyanti, Syofiani, Ramadhan, \& Mukhaiyar, 2018) since it implemented classroom mixed-methods research where the teacher shared equal roles with the students to empower them to become the agents of their language learning change, progress and achievement. The teacher in this research acted more as a facilitator rather than a controller (cf. Chaffee, Noels \& McEown, 2014).

The present study also aimed to enrich the study by Pawlak (2018). While Pawlak (2018) focused on investigating advanced learners' strategy use before, during and after the performance of two communicationbased tasks, this paper reported multiple strategies used by the teacher researcher to empower students to develop public speaking skills. Pawlak (2018) revealed that lack of language learning strategies prevented learners from employing certain strategies in speaking. He also pointed to the lack of research on speaking strategies used by EFL learners. This research attempted to contribute to the current literature by integrating independent learning, assessments and students' reflections to facilitate students' public speaking developments while being aware of the cultural barriers that might otherwise hinder the students' performance. This article argues that integrating more than one learning strategy with the teachers acting more as facilitators would empower students' public speaking skills, an area of research which has gained little attention, particularly in the foreign language learning context (cf. Pawlak, 2018).

\section{Indonesian Cultural Values and Public Speaking}

It has been argued in the introduction section of the article that Indonesian cultural values may inhibit Indonesian students from speaking in public successfully. Some values that could impede their success are the inclinations to avoid direct communications, to speak slowly and carefully in order to avoid public embarrassment, and to use body language and gestures to get the message across (Moffatt, 2012). Indonesian people also prefer to hide their emotions and avoid accountability as well as divert attention from themselves to other people (see e.g., Nadar, 1999; Abdullah, 2016). Another characteristic is preference for equilibrium and kinship (Hermawan \& Loo, 2019). These beliefs may oblige Indonesian people (read Javanese) to hide themselves and do selfdenial (Murtisari, 2013). These traits, while highly needed in order for Indonesians to function properly and successfully in the society, may in fact prevent them from performing successfully when speaking in public. For example, in public speaking, speakers will be successful when they could communicate their ideas directly, clearly, and confidently using both verbal and non-verbal communication strategies. Choosing body language and gestures to replace rather than accompany verbal messages (cf. Moffatt, 2012) may result in poor interactions with the audience, and this will likely make their public speaking less effective, if not a failure.

Public speaking also encourages making use of the speakers' and audience emotions, particularly when they speak to persuade. Avoiding revealing one's emotions in speaking (see Nadar, 1999, p. 2; Abdullah, 2016) may lead to speaking failures. In addition, when conducting a public speaking activity, students should be independent and responsible for the message they deliver. They should not rely on other people to do the job for them and to be accounted for the message. Thus, they should learn to prioritize a sense of individualism rather than kinship as suggested by this Indonesian cultural value (cf. Hermawan \& Loo, 2019). In other words, to be able to convey the message to the audience successfully, students should develop self-confidence, which relates to both efforts and attitudes towards their own public speaking competence (Stewart, McConnell III, Stallings, \& Roscoe, 2017).

Despite the seemingly less favorable cultural values, several studies have shown that Indonesians are open to new and foreign values. As indicated in the introduction, the style of government in Yogyakarta Special Regency has successfully integrated Western democracy (see Tolo, 2013), and meetings of different cultures might not be preventable, which in turn may lead to the birth of a new culture (Humaedi, 2013). Indonesians are also adaptable to new cultural values while at the same time clinging to their own traditional cultures (see, Kusciati, Susilorini, \& Febriary 2013). This is made possible by their tendency to negotiate, embrace and adjust to incoming values (see, e.g., Andries, 2018; Andriani, Udasmoro, \& Suhandano, 2019).

Positive attitudes to foreign cultures lend ample opportunities for Indonesian students to learn public speaking skills, which might traditionally be in contradiction with their cultural values. The challenge 
for teachers, lectures and trainers of public speaking in the Indonesian learning context is how to find learning strategies which conform to the culture of balance and relationship (see Hermawan \& Loo, 2019) while at the same time encouraging students to develop language competence, public speaking skills and strategy use (Chou, 2018). A recent study (Nash, Crimmins, \& Oprescu, 2016) indicates that even native speakers of English face difficult challenges when speaking in public. They suggest more research on strategies to assist students to increase their confidence, use eye contact and gestures effectively, and speak conveniently in front of an audience. They also recommend administrating public speaking assessments, which are congruent with learning activities.

The adoption of multiple learning strategies in this research aimed to fill in the gap in the literature on strategies to empower students to work together in the preparation, presentation and evaluation of their public speaking performances. The class learning designed in this research precisely aimed to handle the cultural barriers facing EFL learners in public speaking while making use of the supportive learning cultures, which are already highly valued in the society. Implementing these strategies will transfer the burden of learning from individual learners to the whole class, which is in harmony with Indonesian harmony and kinship cultures (see the class learning below). This article argues that integrating multiple learning strategies will empower students' public speaking skills as the obligation of having to speak in public is shared amongst students and with the lecturer.

\section{METHODS}

This study employed classroom mixed-methods research where the teacher shared equal roles with the students to empower them to become the agents of their language learning change, progress and achievement (cf. Rainey, 2000; Jing, 2005; Burns, 2010; Banegas, 2011; Creswell, 2012). It collected both quantitative and qualitative data from four groups of public speaking classes at Sanata Dharma University, Yogyakarta, Indonesia from August 2017 to June 2018. The students were enrolled in two semesters of Public Speaking classes with each semester consisting of two classes. The number of students who agreed to participate in the research was 56 consisting of 20 males and 36 females with the mean age of 20 . The data collection was accomplished through Google Forms where students filled out a consent form in order to participate.

\section{Data Collection instruments}

Quantitative data in the form of four sets of Likert type questionnaires were collected at the end of the classes. The first questionnaire asked students to indicate their agreement to questions about reflections, the second about assessments, the third about the combinations of the teaching methods, and the fourth about the students' perceived improvements in public speaking skills at the beginning and at the end of the program. Questionnaires can be found in Appendix 1 (pp. 26-29). Qualitative data aimed to enrich the findings from quantitative data and were collected from students' Focus Group Discussion (FGD) on three reflective questions: (1) What are the benefits of the learning plan and progress report in Public Speaking class?; (2) In what way have you developed in Public Speaking class?; and (3) Are you planning to make your own learning plan and progress reports after completing Public Speaking class? These data were collected at the end of the semester.

\section{Data Analysis}

Descriptive statistics were employed focusing on the means of the students' responses to questionnaires about reflections, assessments, and the combinations of the teaching strategies. Paired samples t-test was performed to determine whether or not there was a significant difference in students' perceived improvements about their public speaking skills before and after their participation in the research. Quantitative data analyses were conducted using SPSS 17. Qualitative data analyses focused on finding major issues and themes in relation to: (1) the benefits of the learning plan and progress report in Public Speaking class?; (2) how students have developed in Public Speaking class?; and (3) whether or not students were planning to continue making learning plans and progress reports after completing Public Speaking class?

\section{Typical Public Speaking Learning Procedures}

Typical classroom learning activities in my public speaking classes began with the students' progress reports to the teacher about their public speaking plans and activities outside the class. They were followed by group discussion and sharing, with the teacher moving around the class listening attentively and giving comments and feedback, when necessary. The students were then split up into several small groups. Each group was given a chance to choose where they wanted to perform public speaking activities either inside the class or outside the class. In the group, the students would in turn present 
their prepared speech to the group. While presenting, the speaker was assessed by other group members using the public speaking rubric (see Appendix 2, p. 30). At the end of the presentation, the speaker had a chance to reflect on his or her presentation by filling out the same rubric. After every one in the group had presented, the completed rubric would be returned to the person. It was then followed by group discussion. The teacher would move around the groups, watching, listening, and participating in the group discussion.

When this activity was finished, everyone returned to class. In class, the teacher would give the students an opportunity to share their experiences and asked questions. Class discussions ended with each individual student writing a reflection about the learning experiences making use of the feedback from peers, the teacher, and themselves. These reflections became the basis for them to make weekly learning plans. The plans consisted of the learning goals and activities to undertake outside the class, independent of the teacher's intervention. Outside the class, each student would pursue their individual learning goals and activities, either in groups or individually. The activities aimed to empower their public speaking skills as listed in the public speaking rubric. To do so, they were encouraged by the teacher to make use of the online learning materials. The students were also expected to make their public speaking outlines and speeches for the following class. At the end of the activities, which included practicing presenting the speech based on the outline, the students would make a reflection about their public speaking performance and filled out the rubric. The assessments on students' progress and achievements used the same rubric the class had been using both inside and outside the class.

From the research design, it was clear that the class learning, including assessments, was conducted in cycles integrating independent learning, progress reports, peer, teacher and self-assessments, and reflections. This approach served to take away the tension of class learning that focused too much on testing rather on students' learning and empowerment.

\section{DATA ANALYSIS}

This section presents findings from both quantitative and qualitative data analyses.

\section{Perceptions about of reflections}

As indicated in the Table 1 all participants showed a very high agreement to the six statements (ranging from Mean 4.44/Item 5 to Mean 4.61/Item 6) about the role of
Table 1. indicates the students' responses towards the use of reflections in public speaking class.

\begin{tabular}{|c|l|c|c|}
\hline No. & \multicolumn{1}{|c|}{ Statement } & Mean & $\begin{array}{c}\text { Std. } \\
\text { Deviation }\end{array}$ \\
\hline 1 & $\begin{array}{l}\text { Reflections in class and } \\
\text { ability to plan, monitor and } \\
\text { evaluate learning }\end{array}$ & 4.51 & .68 \\
\hline 2 & $\begin{array}{l}\text { Reflections outside class and } \\
\text { ability to plan, monitor and } \\
\text { evaluate learning }\end{array}$ & 4.49 & .63 \\
\hline 3 & $\begin{array}{l}\text { Assessments helped deep } \\
\text { reflections }\end{array}$ & 4.54 & .57 \\
\hline 4 & $\begin{array}{l}\text { Reflections help me } \\
\text { understand strengths and } \\
\text { weaknesses }\end{array}$ & 4.51 & .57 \\
\hline 5 & $\begin{array}{l}\text { Reflections grows } \\
\text { responsibility }\end{array}$ & 4.44 & .57 \\
\hline 6 & $\begin{array}{l}\text { Reflections help me become a } \\
\text { better public speaker }\end{array}$ & 4.61 & .56 \\
\hline
\end{tabular}

reflections in developing public speaking. They strongly agreed that they became more responsible learners (Item 5/ Mean, 4.44), better in planning, monitoring, and evaluating their public speaking skills through reflection in class (Item 1/Mean, 4.51) and outside class (Item 2/ Mean 4.49). In addition, they acknowledged the positive contributions of the peer-, teacher- and self-assessments to their ability to make deep reflections (Item 3/Mean, 3.54). As admitted by the students' high responses, reflections were powerful in helping them understand their strengths and weaknesses (Item 5/Mean, 4.44). Item 6, which asked students' overall assessment about their public speaking skills, showed the highest agreement (Mean 4.61) where students admitted that they became a better public speaker after joining the class. The overall students' positive responses to the role of reflections in public speaking class reiterate the importance and power of reflections in students' learning, progress and achievement.

\section{Perceptions about peer, self- and teacher- assessment}

The Table 2 shows the students' high mean responses to three types of questions regarding the contribution of assessments to their public speaking skills. Items 1-3 asked students to indicate whether they learnt a lot about their public speaking skills from various assessments. Items 4-6 invited students' responses towards the contributions of various assessments to their ability in monitoring their strengths and weaknesses in public 
Table 2. demonstrates students' responses towards the use of various assessments in public speaking class.

\begin{tabular}{|c|c|c|c|}
\hline No. & Statement & Mean & $\begin{array}{c}\text { Std. } \\
\text { Deviation }\end{array}$ \\
\hline 1 & $\begin{array}{l}\text { Contribution of regular } \\
\text { peer assessments on public } \\
\text { speaking skills }\end{array}$ & 4.57 & .56 \\
\hline 2 & $\begin{array}{l}\text { Contribution of the lecturer's } \\
\text { assessment on public } \\
\text { speaking skills }\end{array}$ & 4.57 & .56 \\
\hline 3 & $\begin{array}{l}\text { Contribution of regular } \\
\text { self-assessments on public } \\
\text { speaking skills }\end{array}$ & 4.32 & .71 \\
\hline 4 & $\begin{array}{l}\text { Contribution of peer } \\
\text { assessments on monitoring } \\
\text { strengths and weaknesses }\end{array}$ & 4.61 & .56 \\
\hline 5 & $\begin{array}{l}\text { Contribution of self- } \\
\text { assessments on monitoring } \\
\text { strengths and weaknesses }\end{array}$ & 4.44 & .63 \\
\hline 6 & $\begin{array}{l}\text { Contribution of lecturer's } \\
\text { assessments on monitoring } \\
\text { strengths and weaknesses }\end{array}$ & 4.54 & .57 \\
\hline 7 & $\begin{array}{l}\text { Whether peer, teacher- and } \\
\text { self- assessments in the tests } \\
\text { were objective }\end{array}$ & 4.58 & .56 \\
\hline 8 & $\begin{array}{l}\text { Attitude towards peer, } \\
\text { lecturer, and self-assessment } \\
\text { in weekly learning activities }\end{array}$ & 4.44 & .63 \\
\hline 9 & $\begin{array}{l}\text { Attitude towards peer, the } \\
\text { lecturer, and self-assessment } \\
\text { in the tests }\end{array}$ & 4.47 & .63 \\
\hline
\end{tabular}

speaking. Items 7-9 focused on students' attitudes towards various assessments in class and in the test.

Students agreed that they learned a lot about their public speaking skills from various assessments with peer- and lecturer's assessments (Items 1 and 2) showed the highest mean (4.57) and self-assessment (Item 3) the lowest mean (4.32). They also indicated the highest agreement (Mean 4.61/Item 4) regarding the role of peer assessments based on the rubric on their ability to monitor their strengths and weaknesses in public speaking. The second highest response was Item 6 (Mean 4.54) whereby students had high favor towards the lecturer's assessments. The contribution of self-assessments (Item 5) towards their ability to monitor their strengths and weaknesses in public speaking recorded the lowest response (Mean 4.43). It seemed that students needed more training to learn from self-assessments rather than relying more on external assessments. The last three questions (Item 7-9) indicated students' positive attitudes towards the assessments in the tests and in the weekly learning activities. Students believed that being assessed by peers, the lecturer, and themselves in the tests was an objective way to measure their public speaking skills (Item 7/ Mean 4.57) and that they liked being assessed by peers, the lecturer, and themselves in the tests (Item 9/Mean 4.46). The lowest response for this group of questions was Item 8 (Mean 4.43) where students demonstrated positive attitudes towards assessments by peers, the lecturer, and themselves in the weekly learning activities. Overall, students showed positive attitudes towards the implementation of peer-, teacher- and self-assessments in public speaking class.

\section{Combinations of strategies}

The table 3 indicates very high students' agreements to the ten attitudinal statements on the implementations of multiple strategies in public speaking class. The highest agreement was found in Item 10, i.e., with the students' admitting that they were motivated to continue learning independently after taking public speaking class (Mean 4.68). The second highest agreement was shown in the students' response to Item 4 (Mean 4.61). Students agreed that the combination of public speaking rubric, learning assessments, reflections and progress reports in public speaking class made them become a better public speaker. Three statements demonstrated the same level of students' agreements (Item 1, 2, \& 7/Mean 4.58). Students showed strong agreement to the combination of public speaking rubric, learning assessments, reflections and progress reports in public speaking class (Item 1). They also favored highly the contribution of the combination of public speaking rubric, learning assessments, reflections and progress reports in public speaking class in helping them to be an independent learner (Item 2). In addition, they admitted that the combination of public speaking rubric, learning assessments, reflections and progress reports in public speaking class make them become a better learner (Item 7). However, though still very high, the students' responses to the influence of multiple strategies on their becoming responsible learners showed the lowest mean (Mean 4.32).

Qualitative data strengthened the findings from the quantitative data regarding the benefits of various learning strategies implemented in public speaking class. For example, Focus Group Discussion 1 highlights the contributions of learning plans and progress reports on students' ability to monitor and assess their learning achievement: 
Table 3. presents students' responses towards the combination of multiple learning strategies in public speaking class.

\begin{tabular}{|c|c|c|c|}
\hline No. & Statement & Mean & $\begin{array}{l}\text { Std. } \\
\text { Deviation }\end{array}$ \\
\hline 1 & $\begin{array}{l}\text { Attitude toward the } \\
\text { combination of various } \\
\text { learning strategies in public } \\
\text { speaking }\end{array}$ & 4.58 & .56 \\
\hline 2 & $\begin{array}{l}\text { The combination of various } \\
\text { learning strategies and being } \\
\text { an independent learner. }\end{array}$ & 4.58 & .56 \\
\hline 3 & $\begin{array}{l}\text { The combination of various } \\
\text { strategies and being a } \\
\text { responsible learner }\end{array}$ & 4.31 & .71 \\
\hline 4 & $\begin{array}{l}\text { The combination of various } \\
\text { learning strategies and self- } \\
\text { understanding }\end{array}$ & 4.61 & .56 \\
\hline 5 & $\begin{array}{l}\text { The combination of various } \\
\text { strategies and awareness } \\
\text { about success }\end{array}$ & 4.43 & .63 \\
\hline 6 & $\begin{array}{l}\text { The combination of various } \\
\text { learning strategies and being } \\
\text { a better public speaker }\end{array}$ & 4.54 & .57 \\
\hline 7 & $\begin{array}{l}\text { The combination of various } \\
\text { learning strategies and } \\
\text { becoming a better learner }\end{array}$ & 4.58 & .56 \\
\hline 8 & $\begin{array}{l}\text { The methods of learning } \\
\text { in public speaking made } \\
\text { learning fun }\end{array}$ & 4.43 & .63 \\
\hline 9 & $\begin{array}{l}\text { I am a better learner after } \\
\text { taking public speaking class }\end{array}$ & 4.47 & .63 \\
\hline 10 & $\begin{array}{l}\text { Motivation to learn } \\
\text { independently after class } \\
\text { completion }\end{array}$ & 4.68 & .54 \\
\hline
\end{tabular}

Reflection and progress report can be used to help us to monitor and assess our achievement or progress in learning public speaking from the beginning until the end of the semester, know about everything we learned during the teaching and learning process inside or outside classroom and everything we need to improve to increase our public speaking performance skills, whether we have developed ours or not yet (FGD 1).

They also mentioned that learning plans helped them to create better learning strategies and time management:
Learning plan can be used to help us to create better strategies for us to make a good speech (both informative speech and persuasive speech), manage our time wisely because we already have a schedule which set our time to practice so that we can decide a right time for doing certain useful activities, such as brainstorming ideas, making an outline and script of speech, and doing repetition of practice. It can also help us to organize our material well, focus on a particular target in learning, and manage our time. (FGD 5).

Other groups, for example, Group 9, asserted the benefits in terms of time management and knowledge improvement.

We become a person who can manage our time wisely especially in our practice. In our activities that we had done, there are so many things that can improve our skills in our progress and it is very meaningful for us. We also can get some knowledge through the media that we use, such as videos on Youtube or any other media, films, movies, and songs in order to help us to become a good speaker (FGD 9).

Similarly, Group 3 asserts that the multiple learning strategies in class helped them to be more responsible for themselves, understand what they lacked and led them to work on our skills that they lacked. The multiple learning strategies also taught them to assess themselves critically and wisely (FGD 3 ). They also added how the learning strategies in class pushed them to form a good learning habit and ability to do self-assessment:

The benefits of the weekly individual learning plan and progress repost are the habit of practice of public speaking and the evaluation during the week from the Public Speaking. We can know the weaknesses from our public speaking and we know the improvement in the public speaking in every week. Not just depend on the friend's evaluation but it is also from self-evaluation. We can know the progress from the week 1 until the last week about the improvement in the weaknesses.

Students valued having clear plans in learning as seen from this group's discussion result as reflected by Group 6:

The benefits of the weekly individual learning plan and progress report are so many. Based on our thoughts, weekly individual learning plan can make 
everything that we want to do become easier and clearer because we already have a plan to do, and progress report helps a lot to make us know about our weakness, then we can avoid our weakness in the future, it also helps us to increase our skills in public speaking, those 2 things literally help us to realise that we still make lots of mistakes, also it makes everything that we want to do become clearer and easier (FGD 6).

\section{Public Speaking Skills before and after joining the class}

a. Paired samples t-test comparing means of students' responses to twelve items of public speaking skills

Tables 4-6 show the results of the paired samples t-test comparing means of students' responses on twelve items of public speaking skills measured prior to and after joining public speaking classes.
A paired sample t-test was conducted to examine scores on students' perceived public speaking skills as the dependent variable measured prior to and after taking the class. The result demonstrated a significant perceived improvement between the pre-participation level, 2.67, $\mathrm{SD}=.95392$, and post participation level, 4.15, SD $=.58575, t(336)=-25.12, p<.05$. Therefore, the null hypothesis was rejected and the alternative hypothesis was accepted. It can be concluded that multiple learning strategies implemented in public speaking class was perceived by the students to positively impact on their public speaking skills.

\section{b. Paired samples t-test comparing means of students' responses to three items of public speaking skills and culture}

The following three tables (Table 7-9) show the students' responses regarding body movements, interaction with the audience and confidence. These three areas of public

Table 4. Paired Samples Statistics

\begin{tabular}{|l|l|l|l|l|l|}
\hline \multicolumn{2}{|l|}{} & Mean & N & $\begin{array}{l}\text { Std. } \\
\text { Deviation }\end{array}$ & $\begin{array}{l}\text { Std. Error } \\
\text { Mean }\end{array}$ \\
\hline Pair 1 & $\begin{array}{l}\text { Public Speaking Skills before taking Public speaking } \\
\text { class }\end{array}$ & 2.6766 & 337 & .95392 & .05196 \\
\cline { 2 - 6 } & $\begin{array}{l}\text { Public Speaking Skills after taking Public Speaking } \\
\text { class }\end{array}$ & 4.1513 & 337 & .58575 & .03191 \\
\hline
\end{tabular}

Table 5. Paired Samples Correlations

\begin{tabular}{|l|l|l|l|l|}
\hline \multicolumn{2}{|l|}{} & N & Correlation & Sig. \\
\hline Pair 1 & $\begin{array}{l}\text { Public Speaking Skills before taking Public speaking } \\
\text { class \& Public Speaking Skills after taking Public } \\
\text { Speaking class }\end{array}$ & 337 & .083 & .131 \\
\hline
\end{tabular}

Table 6. Paired Samples test

\begin{tabular}{|c|c|c|c|c|c|c|c|c|}
\hline & \multicolumn{5}{|c|}{ Paired difference } & & & \\
\hline & & & & \multicolumn{2}{|c|}{$\begin{array}{l}95 \% \text { Confidence } \\
\text { Interval of the } \\
\text { Difference }\end{array}$} & & & \\
\hline & Mean & $\begin{array}{c}\text { Std. } \\
\text { Deviation }\end{array}$ & $\begin{array}{l}\text { Std. } \\
\text { Error } \\
\text { Mean }\end{array}$ & Lower & Upper & $\mathrm{t}$ & $\mathrm{df}$ & $\begin{array}{c}\text { Sig. } \\
\text { (2-tailed) }\end{array}$ \\
\hline Pair 1 Public Speaking before- & \multirow[t]{2}{*}{-147.478} & \multirow[t]{2}{*}{107.741} & \multirow[t]{2}{*}{.05869} & \multirow[t]{2}{*}{-159.022} & \multirow[t]{2}{*}{-135.933} & \multirow[t]{2}{*}{-25.128} & \multirow[t]{2}{*}{336} & \multirow[t]{2}{*}{.000} \\
\hline Public Speaking after & & & & & & & & \\
\hline
\end{tabular}


Table 7. Paired Samples Statistics

\begin{tabular}{|l|l|c|c|c|c|}
\hline \multicolumn{2}{|c|}{} & Mean & N & Std. Deviation & Std. Error Mean \\
\hline \multirow{2}{*}{ Pair 1 } & My body movement BEFORE & 2.36 & 56 & 0.819 & 0,109 \\
\cline { 2 - 6 } & My body movement AFTER & 4.07 & 56 & 0.535 & 0,071 \\
\hline \multirow{2}{*}{ Pair 2 } & Interaction with the audience BEFORE & 2.54 & 56 & 0.990 & 0,132 \\
\cline { 2 - 6 } & Interaction with the audience AFTER & 4.18 & 56 & 0.664 & 0,089 \\
\hline \multirow{2}{*}{ Pair 3 } & $\begin{array}{l}\text { My confidence to speak in public } \\
\text { BEFORE }\end{array}$ & 2.50 & 56 & 0.874 & 0,117 \\
\cline { 2 - 6 } & $\begin{array}{l}\text { My confidence to speak in public } \\
\text { AFTER }\end{array}$ & 4.36 & 56 & 0.672 & 0,090 \\
\hline
\end{tabular}

Table 8. Paired Samples Correlations

\begin{tabular}{|c|c|c|c|c|}
\hline & & $\mathrm{N}$ & Correlation & Sig. \\
\hline Pair 1 & $\begin{array}{l}\text { My body movement BEFORE \& My body } \\
\text { movement AFTER }\end{array}$ & 56 & 0.356 & 0.007 \\
\hline Pair 2 & $\begin{array}{l}\text { Interaction with the audience BEFORE \& Interaction } \\
\text { with the audience AFTER }\end{array}$ & 56 & 0.184 & 0.175 \\
\hline Pair 3 & $\begin{array}{l}\text { My confidence to speak in public BEFORE \& My } \\
\text { confidence to speak in public AFTER }\end{array}$ & 56 & 0.248 & 0.066 \\
\hline
\end{tabular}

Table 9. Paired Samples Test

\begin{tabular}{|c|c|c|c|c|c|c|c|c|c|}
\hline & \multirow{3}{*}{ Mean } & \multicolumn{5}{|c|}{ Paired Differences } & \multirow{3}{*}{$\mathrm{t}$} & \multirow{3}{*}{$\mathrm{df}$} & \multirow{3}{*}{$\begin{array}{c}\text { Sig. } \\
\text { (2-tailed) }\end{array}$} \\
\hline & & \multirow{2}{*}{$\begin{array}{l}\text { Std. } \\
\text { Dev }\end{array}$} & \multirow{2}{*}{$\begin{array}{l}\text { Std. } \\
\text { Error } \\
\text { Mean }\end{array}$} & \multicolumn{2}{|c|}{$\begin{array}{l}95 \% \text { Confidence Interval } \\
\text { of the Difference }\end{array}$} & & & & \\
\hline & & & & Lower & Upper & & & & \\
\hline Pair 1 & $\begin{array}{l}\text { My body movement } \\
\text { BEFORE - My body } \\
\text { movement AFTER }\end{array}$ & -1.714 & 0.803 & 0.107 & -1.929 & -1.499 & -15.984 & 55 & 0.000 \\
\hline Pair 2 & $\begin{array}{l}\text { Interaction with the } \\
\text { audience BEFORE - } \\
\text { Interaction with the } \\
\text { audience AFTER }\end{array}$ & -1.643 & 1.086 & 0.145 & -1.934 & -1.352 & -11.321 & 55 & 0.000 \\
\hline Pair 3 & $\begin{array}{l}\text { My confidence to speak } \\
\text { in public BEFORE - My } \\
\text { confidence to speak in } \\
\text { public AFTER }\end{array}$ & -1.857 & 0.962 & 0.128 & -2.115 & -1.600 & -14.453 & 55 & 0.000 \\
\hline
\end{tabular}

speaking needed to be measured separately since they could potentially pose cultural barriers for Indonesian public speakers.

A paired sample t-test was conducted to examine scores on students' perceptions about their body movements, interaction with the audience and confidence to speak in public as the dependent variable measured prior to and after taking the class. The results demonstrated a significant perceived improvement between the pre-participation and the post participation. For the body movements (eye contact, move, gesture and facial expression) the pre-participation level was, 2.36, $\mathrm{SD}=.819$, and post participation level, 4.07, $\mathrm{SD}=.535$, $t(55)=-15.984, p<.05$. Similarly, interaction with the 
audience showed a significant perceived improvement between the pre-participation level, $2.54, \mathrm{SD}=.990$, and post participation level, $4.18, \mathrm{SD}=.664, t(55)=$ $-11.321, p<.05$. Students also indicated a significant perceived improvement about their confidence in public speaking between the pre-participation level, $2.50, \mathrm{SD}=$ .874 , and post participation level, $4.36, \mathrm{SD}=.672, \mathrm{t}(55)$ $=-14.453, p<.05$. It can be concluded from the results that students had very positive perceptions about their body movements, interactions with the audience and confidence in conducting public speaking after joining the class.

Results from qualitative data analyses below supported the findings from the quantitative data. The following students admitted that they had developed in many areas of public speaking skills. For example, Focus Group Discussions 5 wrote:

By attending in public speaking class, we think that we have already developed our self. The first one is self-confidence; we learn how to control our expression and behavior in front of the audience. The second one is how to deliver the information clearly and interestingly. The third, we have improved on how to develop ideas specifically so it makes the speech not confusing for the audience (FGD 5).

Another groups mentioned the benefits of attending Public Speaking class in relation to specific language skills and competence. For example,

We develop our public speaking performance and how to improve our speech productions (pronunciation, voice volume, fluency, grammar, and articulation) by learning how to make a wellprepared learning plan and doing repetition of practice (FGD C2).

Another group also showed their agreement to the benefits of attending Public Speaking class particularly regarding the strategies implemented in class.

In Public Speaking class, we developed our speaking skills. We practiced to improve our confidence, critical thinking, and how to be a good public speaker. Every week, we practiced in our small group and assess each other with the rubrics given by the teacher [originally the teacher's name]. From the rubrics, we can see our progress and what aspects that we need to improve more. We also made progress reports and reflections every week. We can see our progress from the beginning until now. We can see what to improve and focus on what we should want to improve (FGD C6).

Students showed commitments to continuing making learning plans and progress reports for themselves when asked if they planned to continue the practice now that they had completed Public Speaking class. For instance, Group 9 writes:

Yes, we still have a plan to continue to make our lesson plan and progress report because it is really helpful for us to face another course that needs our speaking skills and make us become a good teacher. The lesson plan and progress report are very useful for our learning progress, we can do some activities that can help us in our learning, it also likes our journal or diary so we can know the activities that we have done during a week and I think it is very interesting. Through these activities, we can know our progress in learning and what the things we need to improve (FGD 9).

\section{DISCUSSION AND CONCLUSION}

This research addresses one overriding research question, i.e., to what extent does the implementation of multiple learning strategies empower the students' public speaking skills? In general, results from both the quantitative and qualitative data analyses demonstrated that the implementation of multiple learning strategies empowered students' public speaking skills.

This study particularly reveals that given the right learning strategies, Indonesian students could overcome cultural barriers and focus on making use of the positive Indonesian cultural values in public speaking. Students in this research demonstrate that rather than hiding their emotions and running away from the learning responsibilities, they were able to make use of these emotions for enhancing learning. This finding therefore negates the prevalent ideas in the society that Indonesian people tend to be reserved, and avoid responsibility and attention (see e.g., Abdullah, 2016; Murtisari, 2013; Nadar, 1999, p. 2). For example, students strongly agreed that they became more responsible learners (Item 5/ Mean, 4.44). Both the quantitative and qualitative data indicated that students were becoming better public speakers. They could empower themselves to focus on strategies to communicate their ideas effectively and directly to the audience rather than employ avoidance strategies in public speaking (cf. Moffatt, 2012). 
Another major finding in this study is related to the combination of peer-, teacher-, and self-assessments, which seemed to align well with the Indonesian culture of harmony and kinship (cf. Hermawan, \& Loo, 2019). These assessments focused on empowering learners to make use of assessments as tools for learning. Too often assessments place a heavy emphasis on testing which causes distress to learners and leads to learning failures. In this research, individual students regularly conducted self-assessments and gained assessments from peers and teachers. These assessments were based on the same rubric and used as the guideline for the weekly class learning, independent learning and class examinations.

Using the same assessment rubric reduced students' anxiety when they performed weekly class presentations and examinations, and helped teachers, peers and individual learners to work together to create harmony in learning. In other words, to be empowering, class learning should integrate Indonesian dialectic culture, which is gained through negotiations and good relations among all people involved (cf. Andries, 2018). In this study, Indonesian harmonious and dialectic cultures were achieved, among others, through students-centered assessments.

In addition, students in this research indicated that they had higher ability to learn from others' assessments than from self-assessments. They also demonstrated more positive attitudes towards being assessed by others than by themselves. It seemed that the culture and practices of assessments at the university, and also at their previous schooling, had negatively impacted on students' ability to believe and learn from self-assessments. Therefore, rather than merely focusing on standardized testing, university learning should be designed to support learners to learn from assessments (cf. Abdolrezapour, Tavakoli \& Ketabi, 2017; Khonbi \& Sadeghi, 2013; Mbato, 2013; Mbato, 2019). In this case, students needed more training to learn from self-assessments rather than relying more on external assessments, and their individual ability to regulate the learning environments (cf. Chaffee, Noels, \& McEown, 2014). Furthermore, trusting assessments from peers more than those from themselves might reflect the tendency of Indonesian people to conceal themselves from public attention (Murtisari, 2013), and to practice responsibility avoidance strategy (cf. Abdullah, 2016; Moffatt, 2012; Nadar, 1999, p. 2). As evidenced by the data, however, increased awareness of these cultural traits has led to students' becoming better and more confident public speakers.

Overall, students viewed these assessments very positively. They liked being assessed by peers, the teacher and themselves both inside and outside the class, and in the tests. These findings strengthen a study by Khonbi and Sadeghi (2013) about the need for teachers to implement peer-, teacher- and self-assessments and to use them for students' learning rather than merely for standardized testing. They also confirm the results from Abdolrezapour, Tavakoli and Ketabi's (2017) research, which revealed that learners' awareness about learning expectations and the assessments could influence their learning performance, success, and motivation. In addition, the administration of assessments in this research resonates well with Nash, Crimmins, and Oprescus' (2016) study, which argued for public speaking assessments that were consistent with students' learning tasks. In brief, assessments should help students to understand their strengths and weaknesses in learning and prompt them to plan, monitor and evaluate their learning progress and achievements.

Three areas of public speaking were separately examined, i.e., body language, interaction with the audience and confidence since they had greater potential to culturally disadvantage Indonesian students in public speaking. It has been pointed out that Indonesian people tend to communicate indirectly, be reserved and avoid responsibility and attention (cf. e.g., Abdullah, 2016; Murtisari, 2013; Nadar, 1999, p. 2). However as revealed by the results of the paired samples t-tests on body language, interaction with the audience and confidence, these cultural traits no longer became barriers for students in public speaking. They admitted becoming more capable to maintain body movements (which consist of eye contact, gestures as well as facial expressions) in accordance with the message. They also could interact with the audience more effectively as required by the context. In addition, students reported growing more confident when speaking in public. These results strengthen the arguments by several Indonesian authors (see e.g., Kusciati, Susilorini, and Febriary 2013; Andriani, Udasmoro, \& Suhandano, 2019) that Indonesian people have the potential to embrace and adjust to different cultural values as long as these new values do not undermine their traditional values. Data in this research clearly demonstrate that Indonesian learners were able to switch successfully between working as a group and to working independently and responsibly. In other words, they became more inter-culturally competent in public speaking.

Furthermore, the learning strategies implemented in this research could reduce public speaking anxiety, which is the main cause of students' failure in public speaking (Bippus \& Daly, 1999; Durlik, Brown \& Tsakiris, 2014; LeFebvre, LeFebvre \& Allen, 2018). Students in 
this research acknowledged becoming more strategic, confident and successful in learning and performing public speaking skills. This finding shed an optimistic wave particularly to Indonesian students' potential to be successful when speaking in public. It was suggested in the introduction section of the article that having to speak in public led to Indonesian students' anxiety, which might be attributable to social and cultural backgrounds (see Anandari, 2015). It was also underlined that (see Moffatt, 2012) Indonesian people were too conscious about public shame reflecting preferences for indirect interactions and over reliance on non-verbal rather than verbal communications. These cultural traits were seen to potentially hinder Indonesian students from gaining success when they were required to speak in public.

However, as demonstrated by both quantitative and qualitative data results, students admitted becoming better learners and public speakers after taking public speaking class. They were able to manage the increased level of anxiety and stage fright because of having to speaking in public (see Bippus \& Daily, 1999; Durlik, Brown \& Tsakiris, 2014; LeFebvre, LeFebvre \& Allen, 2018). Therefore, EFL teachers should not expect students to manage themselves and their learning on their own (cf. Chaffee, Noels \& McEown, 2014). Supporting them to be strategic (see Chamot, 2009a; 2009b; Oxford, 1990; 1994; 2011; 2017; Mbato, 2013) will eventually lead them to becoming more self-regulated learners, who could maximize their learning potential and achieve rewarding academic success (see Zimmerman, 2000; 2008; Mbato, 2013; Daniela, 2015).

Positive results as admitted by the students in this study could not be divorced from the use of reflections. Students indicated that their involvements in reflecting about their public speaking skills both inside and outside the class had empowered them to become better public speakers. Through reflections, they learnt to understand their strengths and weaknesses, and to plan, monitor and evaluate learning, as well as to embrace the learning responsibility. This finding strengthens previous authors' arguments that students' reflections should be an important component of learning because of their positive impacts on learning, progress and achievements (see e.g., Finlay, 2008; Lockley, 2013; Mbato, 2013) and that university teaching should help students build the habits of reflecting about their learning and learning experiences (see Hutchings, 2018).

Findings in this study enriched a study by Pawlak (2018). While Pawlak (2018) focused on investigating advanced learners' strategy use before, during and after the performance of communication-based tasks, this article reports classroom mixed-methods research on the strategies used by the teacher to empower students to develop public speaking skills. Pawlak (2018) argued that lack of language learning strategies resulted in students' inability to employ certain strategies in speaking. This research furthered the argument by demonstrating that EFL teachers need to facilitate students' use of multiple learning strategies. The implementations of reflections, independent learning, progress reports, peer-, teacherand self-assessments in this research showed favorable acceptance among Indonesian EFL learners.

In conclusion, public speaking may linguistically, psychologically and culturally present difficult challenges for many EFL learners. In addition to having to speak well in English, they are expected to speak in front of an audience successfully. It is even more daunting when the performance is being assessed by their teachers. These demands may inherently contradict students' traditional values such as balance, relationships, responsibility avoidance and fear of public shame. Because of these challenges, EFL learners need to be in a learning environment which is safe and supports them to focus on learning rather than merely on testing. This research has shown that facilitating learners' learning helped them to develop themselves as learners and the skills necessary to be successful public speakers. Through independent learning plans and activities, students' reflections, and peer-, teacher- and self-assessments, learners in this research acknowledged becoming more independent, responsible, and better learners. They also admitted becoming more confident and better public speakers after taking the Public Speaking course. Overall, the implementation of multiple learning strategies in this research has empowered students' public speaking skills. They were able to overcome and make good use of Indonesian traditional cultural values that might otherwise have impaired them from developing their public speaking skills.

This study contributes to the body of knowledge in public speaking in two important ways. First, learning to speak in public for non-native speakers of English should begin with raising their awareness about cultural barriers that might inhibit the development of the necessary skills in public speaking. Second, teaching public speaking to EFL students requires the adoption of multiple learning strategies including strategies to confront imminent cultural barriers. This research, therefore, urges public speaking trainers and teachers in EFL settings to include intercultural understanding and multiple learning strategies in their public speaking classes in order to empower students' public speaking skills. 
Despite its encouraging results, this research has a limitation in that it relies on data from students' perceptions. EFL teachers and future researchers may need to administer a valid and reliable test to collect data on students' public speaking skills at the beginning and end of the research. Data from teachers' notes and observations may also be used to enrich findings from students' perceptions. In addition, explicitly raising students' awareness of their cultural values and promoting intercultural understanding as argued above may help them to experience more success in public speaking.

\section{REFERENCES}

Abdolrezapour, P., Tavakoli, M., \& Ketabi, S. (2017). Enhancing learners' emotions in an L2 context through emotionalized dynamic assessment. Studies in Second Language Learning and Teaching, 3(2), 213-243. http://www.ssllt.amu.edu.pl

Abdullah W. (2016). Etnolinguistic Study of local wisdom in ex-residency of Surakarta. Humaniora, 28, 279-289.

Anandari, C.L. (2015). Indonesian EFL students' anxiety in speech production: possible causes and remedy. TEFLIN Journal, 26(1), 1-16.

Andriani, M., Udasmoro, W., \& Suhandano. (2019). Ideological struggles and identity construction within the politics of French linguistics in Indonesia. Humaniora, 31(1), 73-80. https://doi.org/10.22146/ jh.v31i1.34626

Andries, F.F. (2018). The integration of religion and culture to construct social identity through the Pukul Sapu Ritual in Mamala Village, Moluccas. Humaniora, 30, 92-101.

Apriyanti, D., Syofiani, Ramadhan, S., \& Mukhaiyar. (2018). Improving students' public speaking skill through Instagram. A paper presented at International Conference on Language, Literature, and Education (ICLLE 2018). Advances in Social Science, Education and Humanities Research, 263.

Banegas, D. L. (2011). Teachers as 'reform-doers': developing a participatory curriculum to teach English as a foreign language. Educational Action Research, 19(4), 417-432. doi: 10.1080/09650792.2011.625654

Bippus, A.M., \& Daly, J.A. (1999) What do people think causes stage fright?: naïve attributions about the reasons for public speaking anxiety. Communication Education, 48(1), 63-72, doi: 10.1080/03634529909379153

Black, P., \& Wiliam, D. (2018): Classroom assessment and pedagogy. Assessment in Education: Principles, Policy \& Practice, 1-26. doi: 10.1080/0969594X.2018.1441807. https://doi.org/ 10.1080/0969594X.2018.1441807

Boromisza-Habashi, D., Hughes, J.M.F., \& Malkowski,
J.A. (2016). Public speaking as cultural ideal: internationalizing the public speaking curriculum. Journal of International and Intercultural Communication, 9(1), 20-34. doi: 10.1080/17513057.2016.1120847.

Burns, A. (2010). Doing Action Research in English Language Teaching: A Guide for Practitioners. New York: Routledge.

Butler, N.D. (2017). Learning to speak in the digital age: an examination of instructional conditions for teaching public speaking online. Voice and Speech Review, 1-15. https://doi.org/10.1080/23268263.2017.1370 805

Chaffee, K.E., Noels, K.A., McEown, M.S. (2014). Learning from authoritarian teachers: Controlling the situation or controlling yourself can sustain motivation. Studies in Second Language Learning and Teaching, 4(2), 355-387. doi: 10.14746/ssllt.2014.4.2.9

Chamot, A. U. (2008). Strategy instruction and good language learners. In C. Griffiths (Ed.), Lessons from good language learners (pp. 266-281). Cambridge: Cambridge University Press.

Chamot, A. U. (2009a). The CALLA Handbook: Implementing the Cognitive Academic Language Learning Approach ( $2^{\text {nd }}$. ed.). White Plains, NY: Pearson Education.

Chamot, A. U. (2009b). Using student choice in foreign language teaching to make connections to other disciplines. Electronic Journal of Foreign Language Teaching, 6(2), 150-160.

Chou, M. (2018). Speaking anxiety and strategy use for learning English as a foreign language in full and partial English-medium instruction contexts. TESOL QUARTERLY, 52(3).

Creswell, J. W. (2012). Educational Research: Planning, Conducting and Evaluating Quantitative and Qualitative Research (4 ${ }^{\text {th }}$ ed.). Boston: Pearson Education.

Daniela, P. (2015). The relationship between self-regulation, motivation and performance at secondary school students. Procedia - Social and Behavioral Sciences, 191, 2549-2553. https://doi.org/10.1016/j. sbspro.2015.04.410

Dornyei, Z. (2005). The Psychology of the Language Learner: Individual Differences in Second Language Acquisition. Mahwah, NJ: Lawrence Erlbaum.

Dörnyei, Z., \& Ushioda, E. (2013). Teaching and Researching Motivation (2nd ed.). New York: Routledge.

Durlik, C., Brown, G., \& Tsakiris, M. (2014) Enhanced interoceptive awareness during anticipation of public speaking is associated with fear of negative evaluation. Cognition and Emotion, 28(3), 530-540. doi: 10.1080/02699931.2013.832654

Finlay, L. (2008). Reflecting on reflective practice. PBPL 
CETL, Open University, [Online]. Retrieved from http://www.open.ac.uk/opencetl/resources/pbplresources/finlay-1-2008-reflectingreflectivepracticepbpl-paper-52

Gallego, M. (2014). Second language learners' reflections on the effectiveness of dictogloss: A multi-sectional, multi-level analysis. Studies in Second Language Learning and Teaching 4(1), 33-50. doi: 10.14746/ ssllt.2014.4.1.3. http://www.ssllt.amu.edu.pl

Hermawan, M.S., \& Loo, M.K. (2019). The construction of kekeluargaan as an Indonesia's organizational culture. Humaniora, 31(1), 1-13.

Humaedi, A. (2013). Budaya Hibrida Masyarakat Cirebon. Humaniora, 25, 281-295.

Hutchings, P. (2018). Helping students develop habits of reflection: What we can learn from the NILOA Assignment Library. Urbana, IL: University of Illinois and Indiana University, National Institute for Learning Outcomes Assessment (NILOA). http:// www.learningoutcomeassessment.org/documents/ Habits_Of_Reflection_FINAL.pdf

Jing, H. (2005). Metacognition training in the Chinese university classroom: An action research study. Educational Action Research. 13(3), 413-434. doi: 10.1080/09650790500200309

Jin, Y. (2015). The anxiety-proficiency relationship and the stability of anxiety: the case of Chinese university learners of English and Japanese. Studies in Second Language Learning and Teaching, 5(1), 41-63. DOI: 10.14746/ssllt.2015.5.1.3

Khonbi, Z.A. \& and Sadeghi, K. (2013). Self-, peer-, and teacher-assessment: An investigation into Iranian EFL students' attitudes. Studies in Second Language Learning and Teaching, 3(1). 87-107. doi: https://doi. org/10.14746/ssllt.2013.3.1.5

Kusciati K. P., Susilorini, \& Febriary, I. (2013). Trendy veils: young Javanese women between Islam and modernity. Humaniora, 25(3), 308-323.

Krajka, J. (2017). Assessment in the language classroom: Teachers supporting student learning [Review of the book, by Cheng, L \& Fox, J]. Studies in Second Language Learning and Teaching 7(4), 715-720. doi: 10.14746/ssllt.2017.7.4.8

LeFebvre, L., LeFebvre, L.E., \& Allen, M. (2018) Training the butterflies to fly in formation: cataloguing student fears about public speaking. Communication Education, 67(3), 348-362, DOI: 10.1080/03634523.2018.1468915

Lockley, T. (2013). Exploring self-perceived communication competence in foreign language learning. Studies in Second Language Learning and Teaching, 3(2), $187-212$

Mabuan, R. A. (2017). Developing ESL/EFL learners' public speaking skills through Pecha Kucha presentations. English Review: Journal of English Education, 6 (1), 1-10. doi: 10.25134/erjee.v6i1.76

Mbato, C.L. (2019). Indonesian EFL learners' critical thinking in reading: Bridging the gap between declarative, procedural and conditional knowledge. Humaniora, 31(1), 92-101.

Mbato, C.L. (2013). Facilitating EFL learners'self-regulation in reading: Implementing a metacognitive approach in a higher education context. Dissertation, Southern Cross University, Lismore, NSW, Australia.

Moffatt, A. (2012). Indonesian cultural profile. Diversicare: West End, Queensland. Retrieved, August 18, 2019 from http:/www.diversicare.com.au/wp-content/ uploads/2015/10/Profile_Indonesian.pdf

Murtisari, S.T. (2013). Some traditional Javanese values in NSM: from God to social interaction. International Journal of Indonesian Studies, 1, 110-125

Nadar, F.X. (1999). Transfer of Javanese culture in the production of English utterances and its impact on inter-cultural interaction. Humaniora, 11, 1-6.

Nash, G., Crimmins, G., \& Oprescu, F. (2016). If first-year students are afraid of public speaking assessments what can teachers do to alleviate such anxiety? Assessment \& Evaluation in Higher Education, 41(4), 586-600. http://dx.doi.org/10.1080/026029 38.2015.1032212

O’Malley, J. M., \& Chamot, A. U. (1990). Learning Strategies in Second Language Learning. Cambridge: Cambridge University Press.

Omar, Y.G., \& Altaieb, S. (2015). Culture awareness and learning English as a Second Language (ESL). Journal of Modern Education Review, 5(8), 739-757. doi: 10.15341/jmer(2155-7993)/08.05.2015/003

Oxford, R. L. (1990). Language Learning Strategies: What Every Teacher Should Know. Boston: Heinle \& Heinle.

Oxford, R. (1994). Language learning strategies: An update. ERIC Digest, ED376707(October), 1-6. Retrieved from http:/www.ericfacility.net/databases/ERICDigests/ed376707.htm

Oxford, R. L. (2011). Teaching and Researching Language Learning Strategies. Harlow: Pearson Education.

Oxford, R. L. (2017). Teaching and Researching Language Learning Strategies. Selfregulation in Context. New York and London: Routledge.

Pawlak, M. (2018). Investigating the use of speaking strategies in the performance of two communicative tasks: the importance of communicative goal. Studies in Second Language Learning and Teaching 8(2), 269-291. doi: 10.14746/ssllt.2018.8.2.5. http:// pressto.amu.edu.pl/index.php/ssllt.

Rainey, I. (2000). Action research and the English as a foreign language practitioner: Time to take stock. Educational Action Research, 8(1), 65-91. doi: 


\section{$0.1080 / 09650790000200112$}

Retnowati, Y. (2015). Challenges in cross cultural advertising. Humaniora, 27, 340-349.

Scanlan, J. M., \& Chernomas, W. M. (1997). Developing the reflective teacher. Journal of Advanced Nursing, $25,1138-1143$.

SPSS Inc. Released 2008. SPSS Statistics for Windows, Version 17.0. Chicago: SPSS Inc.

Stewart, C.O., McConnell III, J.R., Stallings, L.A., \& Roscoe, R.D. (2017). An initial exploration of students' mindsets, attitudes, and beliefs about public speaking. Communication Research Reports, 00(00), 1-6.

Tolo, E.Y.S. (2013). Dari ortokrasi ke demokrasi: Menyibak sejarah dan survivalitas " demokrasi ala Daerah Istimewa Yogyakarta. Humariora, 25, 270-280.

Yee, K.M., Abidin, M.J.Z. (2014). The use of public speaking in motivating ESL learners to overcome speech anxiety. International Journal on Studies in English Language and Literature (IJSELL, 2(11), $127-135$.
Watkins, C.I. (2014). Strategies for ESL Students in Community Colleges to Develop Their Public Speaking Skills. Master's Projects and Capstones, 87. ttps://repository.usfca.edu/capstone/87.

Zimmerman, B. (2000). Attaining self-regulation: A social cognitive perspective. In M. Boekaerts, P. R. Pintrich \& M. Zeidner (Eds.), Handhook of Self-regulation (pp. 13-39). San Diego, CA: Academic Press.

Zimmerman, B. J. (2008). Investigating self-regulation and motivation: historical background, methodological developments, and future prospects. American Educational Research Journal, 45(1), 166-183. https://doi.org/10.3102/0002831207312909

Zuniga, M., and Simard, D., ( 2016). Observing the interactive qualities of L2 instructional

practices in ESL and FSL classrooms. Studies in Second Language Learning and Teaching, 6(1). 2016. 135158. doi: 10.14746/ssllt.2016.6.1.7. 